\title{
Amsterdaml'og
}

\section{Structure and Facies Analysis of a Carbonate Hydrogeothermal Reservoir within the Southern German Molasse Basin}

Hartwig von Hartmann ${ }^{1}$

Geothermal energy is an increasing part of the worldwide energy supply. There are three geological provinces in Germany with hydrogeothermal potential: the North German Basin, the Upper Rhine Graben, and the Southern German Molasse Basin. Within the Southern German Molasse Basin the hydrogeothermal aquifer comprises carbonate rocks of the Upper Jurassic which were lowered to a depth of approximately $3500 \mathrm{~m}$.

The interpretation shows the distribution of carbonate facies, structural framework, and karst formation. Seismic attributes were used to enhance the visualization of geologic features.

The results help to find locations for hydrogeothermal wells which require high flow rates of hot water.

\footnotetext{
1 Leibniz Institute of Applied Geophysics, Section 1 Seismic-Gravimetry-Magnetics, Stilleweg 2, 30655 Hannover, T: +49(0)511-643-2929, hartwig.von-hartmann@liag-hannover.de
} 